\title{
Accumulative Bad Governance
}

\author{
Sameh Fawzy
}

\begin{abstract}
This article argues that accumulative bad governance over three decades of Mubarak's regime represents one of the main reasons why people revolted. Bad governance contributed to the fall of the regime in three fundamental ways: first, it created the conditions (such as rampant corruption, violation of human rights and absence of rule of law) that served to inspire public action against the rulers; second, it led to the breakdown of core elements critical for regime stability (within the bureaucracy and the judiciary for example) and third, it catalysed the middle-class who played a key role in agitating for the uprisings via Facebook and other social media. However, in exposing the dynamics of bad governance in Egypt, this article suggests that the problem is not only one of governance gone bad but the very 'good governance' paradigm promoted by international actors. By focusing on institutional reform, the good governance paradigm did not capture the way in which actors, processes and values become diffuse across the state-society divide. A relational governance approach would be more analytically useful in capturing and engaging with some of these dynamics.
\end{abstract}

\section{Overview}

The concept of good governance came to the fore in the 1990s ${ }^{1}$ against the backdrop of the failure of adjustment policies and with a view of developing a new recipe for enhancing the efficiency and capacity of governments to deliver. The World Bank, UNDP, as well as many other key international players, promoted the good governance paradigm as another side of the economic liberalisation coin. While some considered it a recycled version of politics (UNESCAP 2011), others argued that it presented a new perspective on development (OHCHR 2007), since it brought to the fore principles such as accountability in societies suffering from the pathologies of authoritarian corruption (UNDP 1997). While some definitions tended to limit the concept to the principles that make democracy function, for example creating representative and accountable government, building a strong and pluralistic civil society and supporting the rule of law and access to justice institutions (AUSAID 2000); others, that highlighted responsive public administration and wider participation, were seen as real indicators of good governance (Graham et al. 2003).

Larry Diamond noted that most of good governance elements require a political will rather than material:
Every government can create an independent counter corruption commission and electoral administration, and every parliament can pass laws giving citizens freedom of information and requiring that officials declare their assets. Every government can decide to tolerate an independent and critical press and a vigorous civil society. These require political will, not economic development or high state capacity. (Diamond 2008)

When the concept of good governance entered the realm of public debate in Egypt in the late 1990 s, it did so as a result of donors' prioritisation of its integration into public policy. Theoretically, the good governance agenda was underpinned on the one hand by the strengthening of the capabilities of Government to perform assigned duties, while on the other hand, creating the enabling environment for people to hold the government accountable for its policies and actions on the other. As such, good governance signified not only the right of citizens to have transparent and accountable government, but also the necessity to capacitate public administration to implement public policies effectively (Diamond and Morlino 2004). In practice, what was lacking in the good governance lens was the ability to capture the relational dimensions of governance in which 
elements of the state-society spilled over, and new cultures of engagement emerged, which were at once both inclusionary and exclusionary.

This article examines how accumulative bad governance in Egypt contributed to the fall of the Mubarak regime in relation to questions of accountability, responsiveness in citizen engagements and rule of law.

\section{Insidious corruption}

Some of the most forceful slogans that catalysed people to join the protests in Tahrir Square were associated with ending corruption. In Mubarak's last years, corruption had become one of the most talked about issues in daily Cairene conversations; in particular since a series of catastrophes had struck the country, leading to the loss of lives and which were all believed to be a consequence of the absence of accountability. The pervasiveness of corruption catalysed the revolution in several ways: first, the absence of accountability mechanisms, second, the alliance between business and the ruling powers was predatory and hence became a source of deep resentment within the public and third, corruption had a spillover effect into wider society and became part of the social fabric. Each of these dimensions of corruption in relation to the uprisings will be dealt with briefly below.

\subsection{Corruption and absence of accountability}

In theory, accountability is a cornerstone of democratic governance and it simply means that those who hold public office must give account for their actions. There are two types of public accountability in a democratic state; vertical and horizontal. Vertical accountability refers to the power of citizens to hold those in power accountable through, for example setting up anticorruption and human rights non-governmental organisations (NGOs), publishing corruption stories in the media and voting in public elections. Horizontal accountability embodies a wide range of institutions that oblige the accountability of officeholders to one another; 'this constraints executive power and so helps protect constitutionalism' (Diamond 1999). Some examples of horizontally accountable institutions are watchdog financial bodies, the judiciary and parliament. In a democratic society, both types of accountability complement each other. In authoritarian regimes vertical accountability is undermined by rigging elections, repressing civil society organisations and cracking down on free media. Also, the authoritarian regimes always outwardly maintain the structures of horizontal accountability but without any substance or effect. For example, a crippled parliament not only prevents genuine accountability, but also legitimises apathetic, irresponsive and corrupt government.

In Egypt, both vertical and horizontal accountability have been most inept. Vertically, the depoliticisation of civil society crippled civic associations' ability to act as a watchdog and demand government accountability (see Abd el Wahab, El Naggar, Tadros, this IDS Bulletin), while the co-option of the media also obstructed its ability to hold the government accountable. Horizontally, one of the most important forums of holding the government accountable, the parliament, had been dominated by ruling party members and government sympathisers. This in itself led to the nomination of MPs and was duly criticised as lacking in any accountability. The parliamentary elections in 2005 witnessed widescale vote purchase, as voters sold their votes in poor areas in return for 30 Egyptian pounds (the price of half a kilo of beef). This amount soared in wealthy areas, such as Nasr city constituency in Cairo, to hit 1,000 Egyptian pounds. Viagra pills, cigarettes stuffed with cannabis, mobile phones, clothes and food varieties were used to gain constituency in the elections. ${ }^{2}$ The parliamentary elections in 2010 were the worst in terms of vote purchase, violence and exclusion of all opponents. ${ }^{3}$

\subsection{Predatory coalition between the ruling party and business}

The convergence of financial interests of actors who were simultaneously in government/ruling party and the business sector opened the door for the emergence and consolidation of highly predatory coalitions. In 2002 alone, as many as 48 high-ranking officials including former cabinet ministers, provincial governors and members of parliament were convicted of influence peddling, favouritism, profiteering and embezzlement (Al Ahram Weekly (2004). ${ }^{4}$ These included a former minister of finance, a former head of the Customs Authority, a former governor of Giza governorate, as well as some prominent bankers for corruption related to unpaid loans; newspapers and lay people spoke about other cases where no official action was taken. 
The Ministry of Administrative Development's role in fighting corruption was only cosmetic, since the relationship between politics and business remained beyond scrutiny. New laws to curb corruption (i.e. the customs and taxes laws and by-laws) existed only on paper and when, in 2007, the Minister of Administrative Reform established the Committee of Transparency and Integrity, its role was strictly consultative: proposing a national strategy and appropriate legal and administrative frameworks to combat corruption and help people to get their complaints heard and properly addressed. ${ }^{5}$

Four major governmental activities were the most associated with corruption: government purchases, customs and taxes, job recruitment and local administration. The latter particularly was described by Dr Zakareya Azmy, the chief of the Mubarak's staff and a parliamentarian, as 'sinking up to its ears in corruption'. Yet Dr Azmy, who was publicly perceived as an outspoken parliamentarian against corruption and maladministration, often voicing critical views more vigorously than opponents themselves, was arrested on charges of corruption after Mubarak stepped down in February 2011.

One case which personified the predatory nature of the business-ruling party coalition was that of the al-Salam Boccaccio 98 ferry disaster. Mamdouh Ismail, an MP, was the owner of the al-Salam Boccaccio 98 ferry which sank on 3 February 2006, shortly after leaving Saudi Arabia on its way to the Egyptian port of Safaga. Only 338 passengers survived out of the 1,414 who were on board. Following the incident, Mamdouh Ismail fled the country, and now lives in the UK. The parliamentary committee that investigated the catastrophe found that the ferry's owner had failed to meet a series of basic safety standards. The committee condemned 'wicked collaboration' between the shipping company and some top government officials. The investigation indicated that the circumstances of the accident 'point to a hideous image of corruption in a utility related to people's lives'. On 27 July 2008, Mamdouh Ismail was acquitted after a two-year trial. Four hours after the verdict came out, the general prosecutor contested the court ruling because of mounting civil discontent and the anguish among families of the victims (Al Masry Al Youm 2008). ${ }^{6}$ It is highly significant that 11 days following the collapse of the Mubarak regime, the general prosecutor ordered a new investigation of the whole case.

\subsection{The spillover effect}

Bribery became systematically entwined in Egypt's daily life. People bribe public employees to get both legal and illegal services (Fawzy Henien 2007a). Although the circles of corruption had expanded, spilt over from state to society to represent almost a normative framework, by default, counter-coalitions emerged against corruption. There was a great uprising against regime policies across all the institutions that comprised the professional middle-class. In universities, the March 9th movement called not only for the independence of universities but also to remove violations of human rights. Not surprisingly, a large segment of participants in the January 25th revolution emerged from the middle-class, and sometimes upper middle-class. They found that corruption was a real impediment to improving and prospering in a safe environment. This may suggest a rethinking of certain ideas that linked revolution and deprivation. Revolution, as the Egyptian case suggests, may occur as a consequence of rampant corruption.

Indeed, the relationship between financial corruption and human rights violations was one of the main catalysts that inspired the January 25 th revolution. It was not only the poor who suffered from corruption but the 'upwardly mobile professional classes' (Fadel 2011). Since 2003, all effort, exerted by Mubarak's son Gamal to widen his constituency through the inclusion of the professional middle-classes and business people in the 'High Policy Committee' within the ruling National Democratic Party (NDP), proved inadequate because the main goal was to co-opt professionals through corruption rather than providing them with authentic opportunities for social mobility.

\section{Apathetic bureaucracy}

If there was one apparatus that Mubarak should have been able to rely on to represent a counter movement to the protests calling for his demise it would have been the bureaucracy. Mubarak's regime had sought for many years to use the bureaucracy to consolidate its supporters. Yet significant sections of the bureaucracy had 
turned against the regime in its latter years. Moreover, the bureaucracy became a symbol of the disconnection between the government and the public. In the January 25th uprisings, the buildings that angry mobs demolished or burned down were government buildings: police stations, local premises of the government, and the main building of the NDP, which also included the National Council for Women and the National Council for Human Rights.

Egypt has one of the oldest bureaucracies in the world. The country's dependence on the Nile for its agriculture has made it a typical example of a 'hydraulic managerial state which prevents the nongovernmental forces of society from crystallizing into independent bodies strong enough to counterbalance and control the political machine' (Wittfogel 1957). Bureaucracy has a unique position in Egyptian society. Despite the mushrooming of private businesses, many Egyptians still like to have a job in government bureaucracy, even with the poor salary and miserable working conditions, because of the security it offers. The role of public bureaucracy markedly changed after the Revolution of 1952, when it began to assume new responsibilities in the agricultural, commercial and industrial sectors. 'The number of civil servants in the government and the public sector has today reached an astounding 6.8 million, with their total income reaching 86.1 billion pounds (from the budget of 2009), an increase of $12 \%$ from the previous year. This is the largest percentage of civil servants for any government institution worldwide' (CIPE 2009).

The expansion of public bureaucracy was seen by successive regimes since the Revolution of 1952 as a real asset for domination. This explains why the size of public bureaucracy increased by 25 per cent in the mid-1980s, even though there was an economic recession during this period (Zaki 1994). Dr Mustafa Kamel El Sayed, a political science professor, noted that Mubarak preferred to increase the role of public bureaucracy and to be close to the bureaucratic elite during his reign (El Sayed 1990).

The expansion of public bureaucracy caused what Nazih Ayoubi called 'Bureaucratic Inflation'; bureaucrats increased in number, while their capacity to perform duties decreased (Ayoubi 1982). The Egyptian government expressed its discontent at the performance of public bureaucracy on many occasions. But there was no decision taken to address the problem. For example, the Minister of Administrative Development indicated in an interview, that 'the administrative corruption in Egypt is incomparable with any country in the world'. Despite this recognition, the government did not take any serious step to curb widespread corruption (October Magazine 1997).

The advantaged position the public bureaucracy enjoyed transformed it into a unique professional class that defended its privileges and hindered policies that undermined its dominance. Egyptian bureaucracy was a model of 'old bureaucracy' in a 'modern state', different from what Peter Evans called 'Embedded Bureaucracy', when people actively collaborate with bureaucracy in using resources, implementing projects, and evaluating policies (Evans 1995).

Historically, the bureaucracy served as an indispensible arm of the Egyptian regime. It ensured stability and order, produced and distributed public goods, punished the enemies of the regime and maintained its grip on power through rigging elections. Mubarak, like his predecessors, expanded bureaucracy, consolidated its power, covered up its human rights violations and distributed benefits to those who occupied key positions in the state apparatus. The amalgamation of the NDP and public bureaucracy resulted in not only a 'partial public service' but was also deployed to prop up the regime.

However, during the last few years, the relationship between Mubarak and its bureaucracy declined; precipitated by their inability to survive on the falling value of their income. The formation of social and political protest movements (see Ali, this IDS Bulletin) emboldened the civil servants within the bureaucracy to rise against the regime, using similar tactics: demonstrations, stand-offs, and sitins. In 2007, for example, around 20,000 employees at the Real Estate Tax Authority went on strike, asking for salary increases and bonuses (Daily Newes Egypt 2007) (see Ali, this IDS Bulletin). In effect what was being eroded was the coalition between the Mubarak regime and its bureaucracy and this led to disintegration within the state apparatus. This can be easily noticed following the first days of the January 25th revolution. The NDP 
leaders, which used to orchestrate pro-regime demonstrations based on the surplus of the public bureaucracy, failed to find support from state bureaucrats during and after the January 25 th nationwide demonstrations.

In addition to the collapse of the coalition between Mubarak and public bureaucracy, the corruption that permeated the bureaucracy had a spillover effect on wider society. The inability of public bureaucracy to perform its duties coincided with a noticeable deterioration in the performance of non-state actors and the private sector. This supports Fukuyama's argument that there is a direct relationship between governance and public culture, in that the accountable and transparent government helps disseminate positive public values in other society organisations (Fukuyama 2004).

The bureaucracy maintained its supremacy in licensing, establishing and monitoring private enterprises, and NGOs. In such a context, it was not possible to establish partnerships between government, private sector and civil society that could create developmental coalitions (Hyden 1997). A government report revealed that consumer trust in economic performance fell under the equilibrium index during the last few months before the January 25th revolution: reaching its lowest point, 72.6, 72.3 and 72.9 in August, September and October 2010, consecutively. Indexes over 100 correspond to countries where a majority of people trust economic performance, while an index under 100 corresponds to countries where a majority of people have less trust in economic performance (Egyptian Cabinet IDSC 2011).

In light of the above, one can say that Egypt introduced a good example of 'apathetic bureaucracy'. In a survey about bureaucracy, the results showed that decentralisation and delegation of authority are absent. The authoritarian political regime had deliberately created a highly centralised public bureaucracy (Yassin 1994) where citizens faced time-consuming processes in public organisations due to the top-down bureaucratic system (Al Masry 1997). In the end, the bureaucracy came to symbolise the decay of the regime and its disconnect with the people, and was targeted as such in the torching of buildings by the public, along with the State Security Investigations apparatus (SSI) premises.

\section{Rule of law and administration of justice}

The rule of law is a fundamental pillar of democratic governance. The absence of the rule of law was one of the main grievances around which people catalysed and mobilised prior to and at the outset of the revolution. Furthermore, a movement within the judges, who were supposed to represent one of the cornerstones of regime stability had turned against it and joined the ranks of the opposition. Hence, the conditions of injustice created a fertile ground for mobilisation, while the resistance of the judges to cooption and their radicalisation strengthened the growing opposition's contestation of regime legitimacy.

The January 25th revolution was a direct reaction towards the lack of justice and human rights violations. The widespread abuse of ordinary citizens' rights provided an environment conducive to wider public participation in anti-regime demonstrations. Not surprisingly, the police stations and security facilities were the first to be attacked by demonstrators on 28 January; for decades the public had perceived them as places for terror, human dignity abuse and indecent treatment.

In principle, the rule of law ensures equity between citizens and allows them to organise their lives, protect the security of persons and property, plan their futures and resolve disputes in a rational and predictable way. In Egypt, there were many obstacles facing the concept and practice of the rule of law, which became acute in the regime's latter years.

A review of the laws passed during Mubarak's regime evidenced its prejudice towards the predatory capitalist class. Evidence of the protection of the monopoly of policies in the economy is one real example (Fawzy Henien 2007a).

The law did not protect people's lives and properties while the law enforcement agencies were accused of human rights violation, in particular because of the interference of the security apparatus in the public prosecution $(A l$ Masry Al Youm 2011) (see Tadros, this IDS Bulletin).

Moreover, the government selectively applied the law - especially in the case of religious freedoms. In Egypt, since sectarian attacks on non-Muslims were heightened in the early 1970 s, neither 
violence brokers nor perpetrators have ever been put on trial (Daily Newes Egypt 2008).

Discrimination faced Christians in many walks of life; restrictions on building and repairing churches, under-representation in elected political bodies, lack of access to key government positions, all of which violated the principle of rule of law (Fawzy Henien 1998).

One of the bloodiest sectarian incidents occurred almost a month before the fall of the Mubarak regime. Some 23 people were killed and almost 70 hurt in the suspected suicide attack, which happened during a New Year's Eve service at the al-Qiddissin (Saints) church in Alexandria. There are unconfirmed reports referring to the involvement of the regime in the attack. The brutal incident was among the reasons that led to widespread angry demonstrations among Egyptians, particularly Christians who noticeably participated in the January 25 th revolution, refusing the unceasing calls made by official religious establishments to step back from participation. This was a unique moment when Christians decided to participate in anti-regime demonstrations, and not to listen to the church voice. This can be attributed to the strong sense of prejudice they felt after the sectarian incident in Alexandria. Not surprisingly, Ghristian-led movements that participated in the demonstrations of January 25th started their organisation following the al-Qiddissin incident.

The Judiciary was supposed to be another important cornerstone for the regime's survival. The disintegration of the implicit pact between the government and the judges represented another major weakening of the foundations of Mubarak's regime, which contributed to the unification of counter coalitions in the wake of the January 25th uprisings.

A number of strategies had been deployed to co-opt judges, such as their appointment as legal consultants in ministries in return for good financial compensation, providing judges with opportunities to travel to Gulf countries, with vast salaries, etc. The rules governing these decisions were not transparent. In addition, the budget of Judiciary, and the monitoring and evaluating of judges, were determined strictly by the minister of Justice, who was part of the government.

Nevertheless there has been, during the last five years, a strong movement among judges called the 'Independence Trend', resisting interference in the Judiciary, which was increasingly radicalised in Mubarak's later years as a consequence of the ruling party's mobilisation to subjugate the judiciary to the authority of the executive through a proposed new judicial law.

\section{Conclusion}

The Mubarak regime carried all the symptoms of bad governance: a crippled accountability system; a captive civil society; absence of rule of law and an irresponsive bureaucracy. Corruption, bureaucratic pathologies and lack of justice vividly contributed to the collapse of the regime. Corruption obstructed development and became a norm in life. The coalition between the regime and its bureaucracy broke down, and unchecked human rights abuses radicalised Egyptians, who are not normally politicised, to take part in the January 25th revolution.

Yet, the case of Egypt does not only expose its poor governance credentials, but it also points to the very limitations of the good governance paradigm as it was externally advocated. The good governance paradigm introduced by foreign agencies focused on promoting accountability, transparency, efficiency, rule of law, decentralisation and participation, by enhancing the institutional capacities of the government. A relational understanding of governance would have proven to be more analytically useful to understanding the spillover effect from state to society, as well as the convergence between them: many actors served on both sides of the equation simultaneously.

As shown above, corruption had a spillover effect into the very fabric of society, and hence the focus on its prevalence within government failed to capture the normative dimensions of its pervasiveness more widely. Furthermore, civil organisations carry, to some extent, the same pathologies of corruption, inefficiency and ineptness. Not only are they unable to exercise pressures on government to fulfil reform policies, but they are also incapable of stimulating grassroots participation in development projects.

Cosmetic governance may have given the outward impression of sound progress yet, in reality, they were often motivated by other political agendas. For example, raising the 
capacity of the security apparatus to use computer systems; modernising public petroleum and gas companies and promoting investment in the area of tourism, were all to serve the direct needs of the regime to maintain its grip on power, raise revenue and distribute patronage to its

\section{Notes}

1 There is a debate in Egyptian society over the Arabic translation of the concept of good governance. All the translations introduced have been criticised. This can be partially interpreted as a lack of apprehension of the magnitude of the concept itself.

2 This was documented in the first report in Arabic on the Parliamentary Election in 2005, entitled Too Much Money... Too Little Politics, conducted by the Egyptian Association for Democratic Transition. It is accessible at www.hrinfo.net/egypt/easd/2005/pr 1 100.shtml

3 The Cairo Institute for Human Rights Studies, an active human rights centre, summarised the whole elections in a few words in a press release: 'The unprecedented climate of intimidation created by the authorities within printed and visual media, especially in independent media; the escalating violent crackdown on the right to peaceful assembly and political participation; and the effective limitation of the campaigning period to only one week are indeed signs that the coming elections will not meet the international standards for free and

\section{References}

Al-Ahram Weekly (2004) 'Catching Up with Highprofile Corruption', 10 March

Al Masry, A. (1997) 'The Basic Foundations of the Performance of Public Employee', Al Adara 29.3: 16-17

Al Masry Al Youm (2011) Revolutionary Justice, Ahmed Ragheb, www.almasryalyoum.com/en/ node/487051 (accessed 31 October 2011)

Al Masry Al Youm (2008) No 1655 [in Arabic] www.almasry-alyoum.com/article2.aspx?Article ID $=191798$ (accessed 21 November 2011)

AUSAID (2000) Good Governance, Guiding Principles for Implementation 3, www.ausaid.gov.au/ publications/pdf/good_governance.pdf (accessed 4 November 2011)

Ayoubi, N. (1982) 'Bureaucratic Inflation and Administrative Inefficiency, the Deadlock in Egyptian Administration', Middle East Studies 18.3: 295-7 loyalists in the form of licences, land, etc. What is suggested here is that 'Relational Governance' manifests itself in political, cultural and socioeconomic interactions, which cannot be captured by a governance approach that focuses heavily on government institutions.

fair elections. Rather, they offer implications that the elections will be based on legislative and constitutional corruption, with the existence of tight administrative and executive control. This confirms that the forging of the will of the voters has started early for this election' (CIHRS 2010).

4 The report introduced one of the unprecedented parliamentary debates around the legal accountability of ministers in Egypt.

5 The Government considered the establishment of the Committee of Transparency and Integrity as one of the important achievements it attained in 60 months, as seen in The Most Important 60 Achievements in 60 Months, a booklet prepared by the Egyptian Cabinet and introduced by the Prime Minister in July 2009.

6 Egypt: Report on Ferry Disaster Condemns Official Corruption, 26-4-2006, World Socialist website, www.wsws.org/articles/2006/apr2006/ ferra26_prn.shtml. For more details about the relationship between the disaster and corruption, see: The Report of the Fact-finding Mission of the Egyptian Organization for Human Rights. The report in Arabic is accessible at www.eohr.org/ar/report/2006/re0219.shtml

CIHRS (Cairo Institute for Human Rights Studies) (2010) Rigging the 2010 Parliamentary Elections in Egypt, www.cihrs.org/English/ NewsSystem/Articles/2715.aspx (accessed 31 October 2011)

CIPE (2009) Tackling the Leviathan: Reforming Egyptian Bureaucracy for Improved Economic Growth, White Papers: 16-17, www.cipe-arabia.org/ files/pdf/Bureaucracy-EN.pdf (accessed 25 October 2011)

Daily News Egypt (2008) 'Reconciliation without Justice', 4 June

Daily Newes Egypt (2007) 'In Focus: The Egyptian Bureaucracy Rebels', 11 December

Diamond, L. (2008) The Spirit of Democracy: The Struggle to Build Free Societies Throughout the World, New York: Times Books: 324

Diamond, L. (1999) Developing Democracy towards Consolidation, Maryland: Johns Hopkins University Press: 10 
Diamond, L. and Morlino, L. (2004) The Quality of Democracy, CDDRL Working Paper 20, September: 7-27

Egyptian Cabinet IDSC (Information and Decision Support Center) (2011) Egyptian Consumer's Trust Index in Economic Performance 8.96

El Sayed, M.K. (1990) 'Bureaucracy and Political Change in Egypt Since 1952', unpublished paper: $12-13$

Evans, P. (1995) Embedded Autonomy, States and Industrial Transformation, New Jersey: Princeton University: 50

Fadel, M. (2011) 'Public Corruption and the Egyptian Revolution of January 25: Can Emerging International Anti Corruption Norms Assist Egypt Recover Misappropriated Public Funds?', Harvard International Law Journal Online 52: 293-5, www.harvardilj.org/online/ (accessed 25 October 2011)

Fawzy Henien, S. (2007a) 'Egypt: Bad Blood', in Jonathan Werve and Global Integrity (eds), The Corruption Notebooks 2007, Washington DC: Global Integrity: 110-11

Fawzy Henien, S. (2007b) Citizenship, Cairo: Cairo Institute for Human Rights: 41-2

Fawzy Henien, S. (1998) Out of Sectarian Tunnel: Coptic Concerns, Cairo: Ibn Khaldun Center for Development

Fukuyama, F. (2004) State Building, Governance and World Order in the Twenty First Century, London: Cornell University Press: 39-41
Graham, J.; Amos, B. and Plumptre, T. (2003) 'Principles of Good Governance in the 21st Century', Policy Brief 15.6, Institute on Governance

Hyden, G. (1997) 'Building Civil Society at the Turn of the Millennium', in John Burbidge (ed.), Beyond Prince and Merchant. Citizen Participation and the Rise of Civil Society, New York: Pact Publications: 30

October Magazine (1997) No. 1084, 3 August

OHCHR (2007) Good Governance; Practices for the Protection of Human Rights, Geneva: Office of the United Nations High Commissioner for Human Rights

UNDP (1997) Re-conceptualizing Governance, Discussion Paper 2, New York: UNDP: 17-19

UNESCAP (2011) What is Good Governance?, www.unescap.org/pdd/prs/ProjectActivities/ Ongoing/gg/governance.asp (accessed 31 October 2011)

Wittfogel, K. (1957) Oriental Despotism, New Haven CT: Yale University Press: 49

Yassin, E. (ed.) (1994) Egyptian Bureaucracy, an Empirical Study, Cairo: Al Ahram Center for Political and Strategic Studies: 65-106

Zaki, M. (1994) Civil Society and Democratization in Egypt 1981-1994, Cairo: Ibn Khaldoun Center for Development Studies: 22-4 